\title{
The seismicity of Iran. \\ The Turshiz (Kashmar) Khorassan earthquake of 25 September, 1903
}

\author{
N. N. AMbraseys $(*)-\Lambda . A$. MoINfar $(* *)$
}

Received on August 18th, 1975

Summary. - The Turshiz (modern Kashmar), Iran earthquake of the 25th September 1903 occeurred in a semi-desertic region, just south of the Dormel fault; it had a magnitude of about 6.5 , it was felt within an area of 200,000 square kilometres and it was followed by aftershoeks for at least 13 weeks. The earthquake killed about 350 people within an area which extended from Turshiz to the Kavir in the southwest. There is no evidence that the earthquake was associated with faulting, but it did cause a temporary ehange in the flow of underground water.

Riassunto. - Il terremoto del 25 Settembre 1903 avvenuto a Turshiz (la modema Kashmar, Iran) in ma zona semidesertica a sud della faglia di Dormels; ebbe una magnitudo di 6.5, un'area macrosismica di $200.000 \mathrm{~km}^{2}$ e fu segruito da repliche per almeno 13 settimane. Vi furono 350 morti in un'area compresa fra Turshiz e Kavir in direzione SW. Non vi è aleuna testimonianza che il terremoto fosse associato o meno ad una faglia, ma è certo ehe causò un eambiamento temporaneo nel flusso di aeque sotteranee.

\section{INTHODLCTION.}

On 25 September 1903, an earthquake affected the district of Turshiz, one of the most fertile parts of Khorassan, in eustern Iran,

(*) Imperial College, Isondon.

(**) Plan \& Budget Organ., Tehran. 
Figure 1. This district, the modern Shahrestan-i Kashmar, is a valley, 80 kilometres long and about 20 kilometres wide, which runs in an east-west direction between two mountain ranges, Figure 2. To the north, the Kuh-i surkh and the Siah-Kuh rise 1,000 metres above the

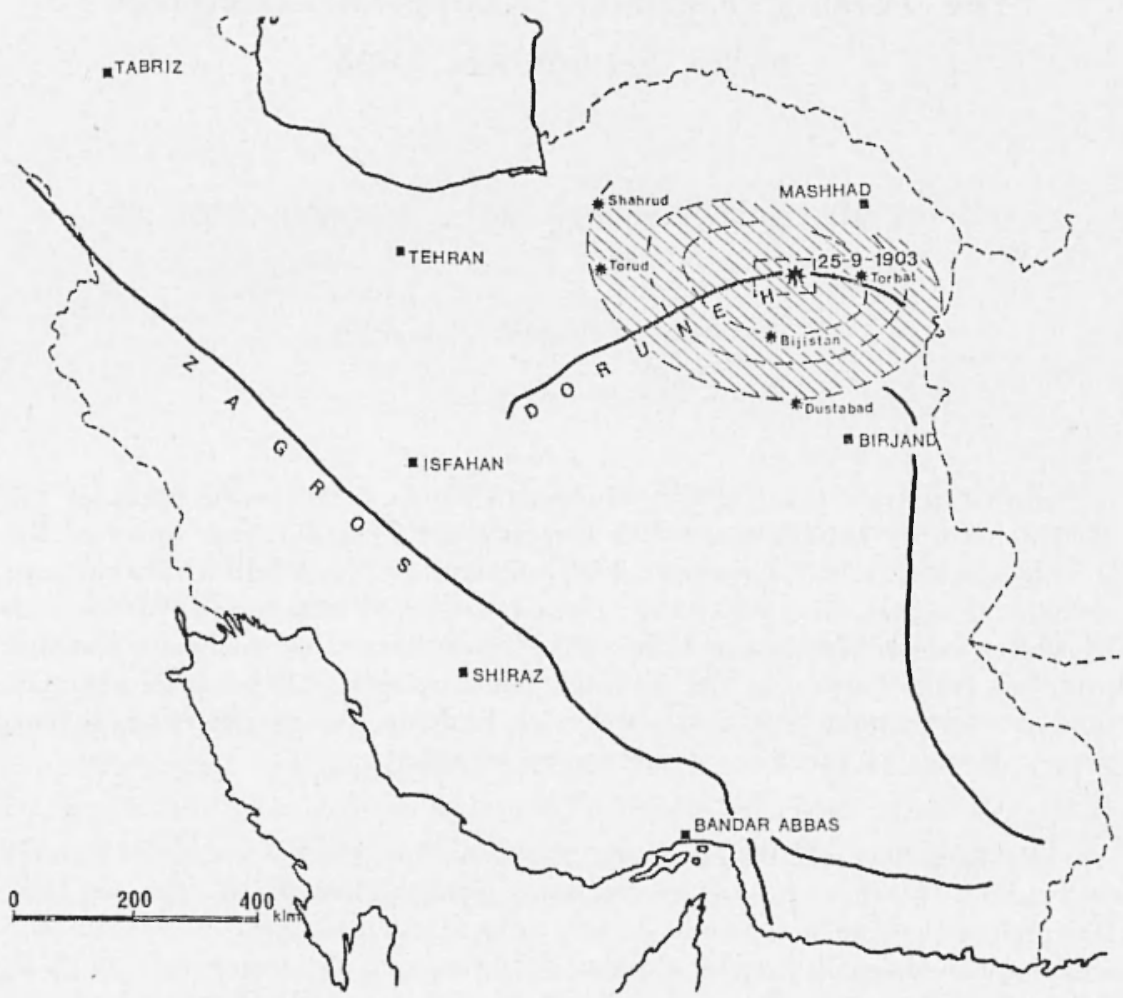

Fig. 1 - Location map of the Turshiz earthquake of 25 September, 1903. Shaded area shows extent of pereeptibility of the shock $(I=$ III) with approximate contours for higher intensities (IV, V). Inset shows area covered by Finure 2.

valley and provide it through most of the year with ample water, which is carried across it in many streams and canals, both on the surface and underground (in qanats). The range on the oposite sicle of the valley, the Kuh-i Begu, is discontinuous and much lower, and separates the Turshiz valley from the low-lying desert of Kavir-i Namak to the south. The fertility of the valley decreases westwards 
THE SEISMICITY OF IRAN. THE TURSHIZ KHORASSAN EARTHQUAKE... 255

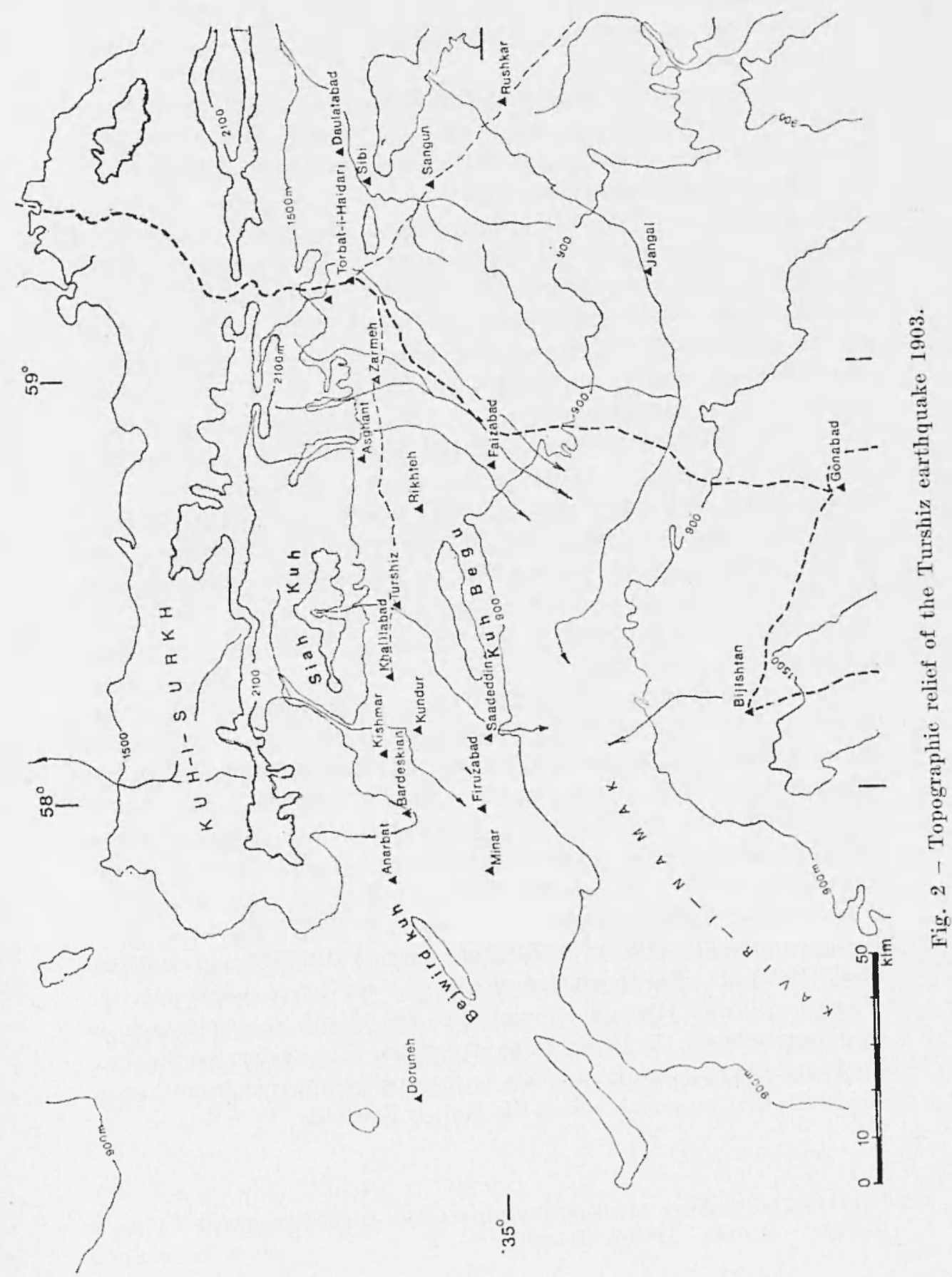


as water becomes more scarce, and past Barleskan (*) towards Anarbat one enters the desert route to Shahrud via Doruneh, or the more direct caravan track, via Turun.

In early times this northwest comer of Kuhistan was known as the district of Busht, of which the chief towns were Turshiz and Kundur. The large village of Kundur is still existing on the west bank of the Rudlihaneh Shishdiraz, but ancient Turshiz is in ruins, abandoned since the 13 th century. Today, the village of Firuzabad has sprung up to the west of the ruins of Turshiz. It seems that the morlern village of Kishmar marks the earliest site in the district, being built around an old settlement of the same name. There is an old legend pertinent to the seismicity of the region; a cypress-tree grew to be larger than any other that har ever been. Such too was its power that in the village of Kishmar no earthquake was ever felt, although, in various other places, of all the neighbourhood round and about, earthquakes were common, Mustawfi ${ }^{(19)}$. However, in the midale of the 9th century Caliph Mutawakkil caused this tree to be fell. It is not known whether after this Kishmar was damaged by earthquakes. As a matter of fact we have been unable to find any information relating to earthquakes in the Turshiz valleys prior to 1903. As for the cypress-tree it is possibly the origin of Marco Polo's "arbre sol", Le Strange (1966) (26), Gabriel (1935) (10).

The special importance of the Turshiz earthquake of 1903 is that it is the first known seismic event to occur on the Dormeh fault zone, an active throughgoing structural element that runs for more than 650 kilometres from the $\Delta$ fghan border in the east into the Dasht-i Kavir in the west (see fig. 1). This fault is shown on the Geological Map of Iran (1959) (12) and it was well known to the geologists of the Geological Survey of Iran before 1959, Gansser (1969) (11). The whole or parts of the zone were surveyed or studied by Wellman (1966) (32), Tchalenko et al. (1973) ( $\left.{ }^{30}\right)$ Stocklin (1973) ( $\left.{ }^{25}\right)$, Eftekhar-Nezhad (1971) (?) and Mohajer et al. (1975) (18). The Doruneh fault shows every sign of recent activity. In places it cuts through alluvial fans and elsewhere displaces in a disorderly manner the most recent structures. The geology of the area bordering the fault to the north is so thoroughly different from that to the south that no match across the fault is possible,

(*) The spelling of place-names is taken from the official "Village Gazetteer of Iran' 1965-9, Tehran. 
The TLRshi (KASHMAR) EARTHQUAKE of 1903.

The Turshiz earthquake of 25th September 1903 (3rol Rajab 1321) occurred at 01 hours 20 minutes GIT. The shock was recorder at more than fifteen stations of the primitive seismic network of the time, and as far away as Kew and Irkutsk, more than 4,500 kilometres from the epicentre. Seismographic results were reported by Glasek (1903) (13), Weigand (1903) $\left(^{31}\right)$, Belar $(1904)\left({ }^{4}\right)$, Levitski (1905) $\left(^{(5)}\right.$ ) and in regular station Bulletins. In 1910 Milne using macroseismic data datermined the origin time of the earthquake at $01 \mathrm{~h} 20 \mathrm{~m}$ and the approximate position of the epicentre at $34^{\circ} \mathrm{N}-58^{\circ} \mathrm{E}$, that is, 140 kilometres due sonth of the macroseismic epicentre, near Ferlows, Milen (1911) (17). More recently, an equally erroneous location is given by Berberian (1973) (5). The earthquake is noticerl by Tams (1908) (28).

The effects of the earthquake received little attention in the Persian and foreign press. The first detailed account of the earthquake we find in the confident: diary of the British consul in Mashad for the week enrling 10th October 1903, enterer by Capt. J. Fisher, acting H. M. Consul (*). He says that there have been severe shocks in Turshiz and that the total deaths resulting are put down at 350. All the carpet manufactories were restroyer, the loss being estimater at 50,000 tumans. He adds that Capt. Yass and the Russian doctor of Torbat-i Hairlari had both been for some days at Turshiz to report on the clamage and look after the numerous injurerl. Capt. Fisher does not say wheter the shocks were felt in Mashar. The earthquake is not referred to subsequently in the Mashar consuliu rliaries.

The Russian roctor to whom Capt. Fisher refers in his diary, was T. Almator (**) director of the Central Merlical Station at Torbat-i Iairlari. After visiting Turshiz, he submitter a report which was published by Levitski (1905) (15), and recently translated into English by Tchalenko (1973) (29). According to Almatov's report, the earthquake in Turshiz occurred at 02 hours 31 minutes; it laster 25 to 30 seconds and the general direction of the shocks were from the northwest. Out of 1,200 houses in the town, 600 were destroyed and about 400

(*) $1.0 .1 / \mathrm{P}^{\prime}$ \& S S/7/159 no. 1637.

$\left.{ }^{* *}\right)$ In some documents the doctor's name is written $A$ lnazov and in others Almatov. 
were severely damaged, the rest were slightly damaged. In the town, most of the damage was concentrated in the south and in the suburbs to the northeast. The nearest of the surrounding villages were also barly damager. Almatov assessed a maximum intensity at Turshiz of $\mathrm{IX}$ on the Rossi-Forel scale and points out that much of the damage was due to the poor materials and methods of construction employed, particularly for roofs, which were heavy marle of thick layers of conpacted soil. He reckoned that the area of destruction extended 21 kilometres to the north, south and east of Turshiz and about 37 kilometres to the west of the town. Within this area 25 villages were destroyed or damaged. In Turshiz alone, 100 people were killed and 100 injuried, Almatov $(1905)(1)$.

Turshiz was the name of the present town of Kashmar, which torlay has a population of about 23,000 . It is a comparatively new settlement fomded in the middle of the 18 th century by Abdul Ali Khan, governor of Herat. Since its fomnlation the town had has its name changed a number of times, from Turshiz to Sultanabad, Sultanieh, back to Turshiz and recently to Kashmar. When Forster passed through it in December 1783, Turshiz consisted of two parts, the old town called also Sultanabal which was a small settlement surrounded with a wall, and a new one built by Abrul Ali being a prosperous town in which 100 Hind families were established in their own quarter. Among its chiefs exports was iron wrought in thiek plates, Forster (1798) ( ${ }^{8}$ ). At the beginning of the 19th century the revenue of Turshiz was estimated at $\& 60,000$ a year but although still prosperous, Uzbegs were annually laying waste its lields and plundering its villages, Malcolm (1829) (16). In 1822 Fraser found Turshiz a ruin, containing 3 to 4,000 inhabitants, having fallen from its prosperity due to bad alministration and heavy taxes, Fraser $(1825)\left({ }^{9}\right)$. The situation in Turshiz was even worst when Clark passed through it in 1857 ; it returned an annual revenue of only $\&$ 9,000 and the town was in ruins; all he conld find in the Turshiz valley was ruined remains of villages, Clark (1861) ('). It seems that in the following generation Turshiz began to fluorish again but lost its original name. Stewart, who was in the town in November 1880, lemarks that all maps marked a town ealled Tu'shiz, but there was no such town and it was only the name of the district, the chief town of which was Sultanabarl: a small fluorishing place of some 5,000 inhabitants with a good deal of trade, silk and wheat being the chief articles exporterl, Stewart (1881) (24). In 1894 Baumgarten reckoned that Turshiz had a population of about 6,000 inhabitants and 
about 1,200 dwellings which covered an area of about half a square kilometre; he estimated that about 80 to 120 villages belonged to Turshiz with a total population of 24,000, Baumgarten (1896) (3).

A series of field studies were carried out by the anthors late in 1962 and in the spring of 1975 . During their stay in the region the authors collected a considerable number of interviews with the inhabitants, mostly with serlentary octogenarians who as young boys rememberel the earthquake, as well as with local people knowledgeable about the history of the district. The general consent of opinion was that only about 150 houses collapsed completely in Turshiz, killing about 80 people. In Bulurian's mahaleh (district of the town) 27 people were lilled and another 7 in the Kujet-i mahaleh. Damage was extensive, particularly in the southern parts of the town where almost all houses were shattered, but few collapsed completely. In the northern suburbs of Turshiz no houses collapsed but almost all of them were barlly cracked and remains of the old town walls fell dlown. Part of the bazar also fell down and the Ivan of the mosque collapsed. There was no rlamage to the minarets but bricks, detached from the parapets of the mosque, were thrown out. In all about half of the houses in Turshiz were either totally ruiner or clamaged to the extent that they had to be pulled down and rebuilt, all of them at the same place; there was no need to relocate the whole or part of the town. It seems that immerliately after the earthquake many of the survivors from nearby settlements and villages, many of them injured, flocked into Turshiz, and although Almator's casualty figures may be ont by a small clifference they may inclucle casualties from neighbouring villages. Al-Qussy (1906) (-1) puts the casualties in Turshiz to only 35 people, possibly a mistake for 350, and Major Sykes who was in the town in November 1909 ( $^{*}$ ) says that it contained a population of $\tau$ to 8,000 inhabitants and adds that the town had suffered considerably during the earthquake, Sykes (1911) (27).

Almatov points out that the water in wells and in the qanats increased after the earthquake, especially in the qanat of Farafin where the flow of water doubled. This may be true for the days immediately following the earthquake. Our information is that there were no long-term effectsin any of the qanats in the Turshiz valley, inclucling those of Fadafin. In some wells and qanats the flow of water increased

(*) Cf. Tehalenko $\left(1973\right.$, p. 34) $\left({ }^{29}\right)$. 
and in others decreased temporarily, eventually coming back to the normal flow it had before the earthquake. The qanats of Dasht-i Shahru were not affected at all.

The damage extended mainly west-sonthwest of Turshiz. At Zendejan, a small settlement of a few houses at the time of the easthquake, there were no casualties but almost all the houses were ruined, and the roof of a number of covered wells (ab-ambars) collapsed. In Dehnow one out of seventy houses collapsed and the rest were banlly damaged; no one was killed but a few people were injured. In Khalilabarl out of 160 houses a dozen of them collapsed killing two people and injuring many; the rest of the honses, some of them in a duinous state even before the earthquake, were shattered. It is said that damagre in Khalilabal was a serious as in Turshiz and that the village was abandoned for sometime. Damage was equally widespread in Nasuatabar, Sarmozdeh and Mozleh. It Nasratabad only one house collapsed completely but the whole village was ruined and most of the houses haul to be rebuilt. The shock haul no permanent effect on the water supply but the ground opened up in places by as much as 10 centimetres, cracks 50 metres long rumning in a sonthwest-northeast clirection to the north of the village. In Mohammadabad four people were killed and many injured; the village was badly damaged and a large rest-house in the middle of it collapsed. In Argha all houses were ruined and a number of old water-mills collapsed. For Inundur the information we have been able to collect is conflicting; it seems that the damage was equally serious as in neighbouring villages but it is not clear whether about 20 people were killed in this village or in outlying settlements to the west of Kundur. In Jabuz no one was killed but all houses were ruined and four collapsed completely, injuring many people. It is alleged that a small number of people, 10 to 20 were killed in two settlements to the northwest of the village, the ruins of which are still extant. The shook was felt very violently in Jabuz, and aftershocks which contimued for about 10 days caused additional damage. It Shefiabad only half of the 60 houses in the village were ruined; it is reported that as a result of the shock, which was very violent, the yield of the qanat watej increased permanently. Unconfirmed information alleged that the small village of Kalughan was also duined. At Bardeskan the part of the village inside the walls was shattered and part of the fort collapsed. The rest of village suffered little damage and no one was killed. However, many outlying settlements to the southwest of Bardeskin are said to have been destroyed with causualties. Although we have not been 


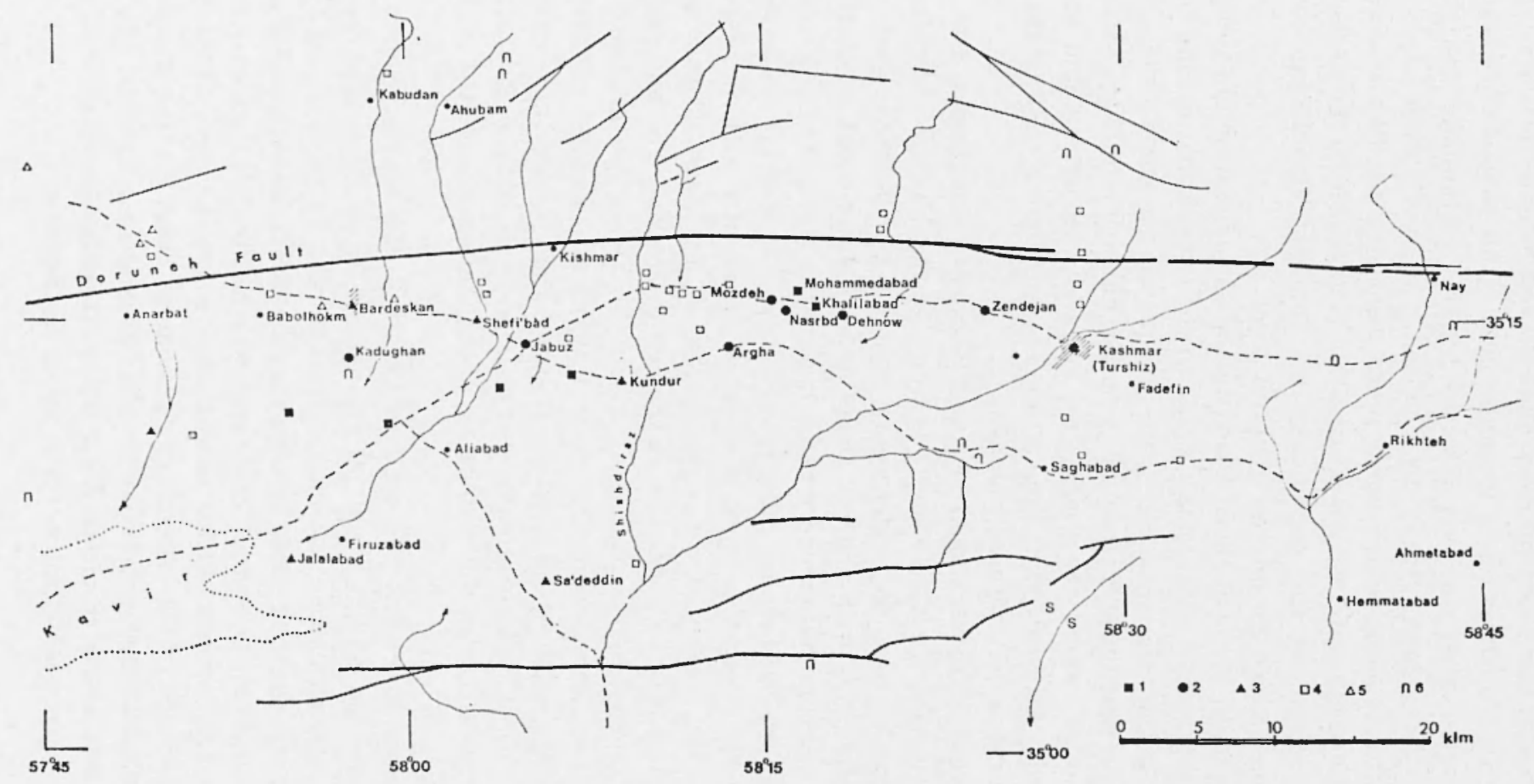

Fig. 3 - Epicentral region of Turshiz earthquake of 1903. 1) - villages almost totally destroyed with fatalities; 2) - villages heavily damaged with casualties; 3) - sites that suffered considerable damage without casualties; 4) - oldsites and water mills extant, as well as abandoned villages; 5) disused ab-ambars; 6) - springs and wells. 
able to irlentify the exact location of these settlements it is perhays interesting that al-Qussy on a marginal note of his manuscripts arlds that the region most seriously aflected by this earthquake was the section of the car"avan track to Shahrul, west of "Badr Ashar" (= Bardaskan?) along which many wells went dry for two seasons, al-Qussy (1906:249 top) $\left.{ }^{20}\right)$. No information is avalable to the anthors about the effects of the earthquake at Anarbat, Babolhokm and Fbrahimabad which lie off the Shahrud track.

To the south of the Shahrud track, Jalalabad suffered small damage but the shock caused considerable panic to the extend that during the aftershock period the settlement was evaquated for some time. It seems certain that the shock causer no serious damage to villages southeast of Aliabad, where the shock was, however, wirlely felt and still remembered. It Sardedlin, the earthquake was strongly felt, lasting almost a minute, but without damage.

At Torbat-i Maidari shocks began at 02 hours 28 minutes and they lasted 25 seconds; the1r direction was flom the northwest. They were accompanied by a strong underground somnd which started about 5 seconds before the main shock. Doors and windows shook violently, beds were swaying and crockery rattled. Almatov assessed an intensity VI on the Rossi-Forel scale for Torbat-i Hailari. The shock was also felt in Bijistan, 80 kilometres south of Turshiz, apparently with the same intensity. The earthquake was pereptible at Dustabad, Torud and Shahrurl there is no evidence that it was felt in Mashad. The minimum randius of perceptibility, therefore, should be about 250 kilometres.

Apart for some evidence for ground deformations, most probably of local nature north of Nasiatabad, it seems that the shaking caused some of the steep banks of streams east of Dehnow to collapse. Rockfalls were also reporter from the mountains, about 9 kilometres to the north of Tushis.

Accorling to Fisher, the earthquake killed 350 people. Almatov puts this down at 199 killed and 261 injured and he considers that there should be more casualties. Al-Qussy gives 35 killed in Turshiz and 281 injured throughout the region; he ahds that the earthquake destroyed all the rug factories in the region. Stahl also, who had travelled extensively in western Iran mentions this earthquake, which he says killed 35 people, Stahl (1911) ("3). According to Sieberg (1932) (21), the Turshiz earthquake killed 209 people in 25 villages excluding Turshiz. It is almost impossible to reconcile these figure, it seems however that at least 350 people were killed in the Turshi\% earthquake. 
The 1903 earthquake was precerled and followed by a rather long sequence of shocks.

1902 Jul. 20 - Two shocks, which were not felt in Torbat-i Haidari, damaged a few houses at Rud-i Majan, Almatov $\left.(1904){ }^{1}\right)$.

1903 Jan. 10 - At $13 \mathrm{~h} 1 \mathrm{sm}$ severe shorks eaused panic in Daulatabad but no damage. These shocks were also felt in Torbat-i Hairlari with an intensity IV Rossi-Forel, lasting for 4 seconds; the ground movements were from south-southeast to north-northwest; Glasek (1903:5) ${ }^{(13)}$, Almatov (1905) ${ }^{(1)}$.

Jun. 19 - Small shocks felt in Torbat-i Haidari; Glasek (1903: 25) $\left.{ }^{13}\right)$, Almatov (1905) ${ }^{(1)}$.

Jun. 20 - More, minor shocks felt in Torbat; Glasek (1903:25) (13) Almatov (1905) ${ }^{(1)}$.

Jun. 21 - At $06 \mathrm{~h} 58 \mathrm{~m}$ accompanied by underground noise, a long-period vibration in Torbat-i Haidari, felt with an intensity III Rossi-Forel, lasting about 30 seconds in a direction from northeast; Glasek (1903:25) (13); Almatov (1905) (1).

Jun. 22 - It $23 \mathrm{~h} 48 \mathrm{~m}$, sharp shocks felt in Torbat-i Haidar accompanied by underground noise, lasting for 2 minutes. The shocks, which were from northeast to southwest, were felt with an intensity $V$ Rossi-Forel, causing people to flee their houses in panic; Glasek $\left.(1903: 25){ }^{(13}\right)$, Almatov (1905) (1).

Jun. 24 - At $01 \mathrm{~h} 03 \mathrm{~m}$, more, rather weak shocks in Torbat; Glasek (1903:25) (13) Almatov (1905) (1).

None of these shocks was recorded at the nearest stations which are about 1,000 kilometres from Torbat-i Haidari. The main shock of 25th September 1903 was followed by the following aftershorks:

Sep. $30-$ It $19 \mathrm{~h} 00 \mathrm{~m}$; this was the strongest aftershock, felt as far as Torba-i Haidari. In Turshiz it lasted 5 seconds and caused additional clamage to the town and villages. It was recorded at a number of seismire station and it was followed by another six shocks of intensity between III and V Rossi-Forel; Almator (1905) (1), Belar (1905: v. 152) (4). 
Oct. 10 - At $21 \mathrm{~h} 03 \mathrm{~m}$, strongly felt at Turshiz, IV; Belar (1905) $\left(^{(4)}\right.$, Almatov $(1905)\left({ }^{1}\right)$.

Oct. 17 - Damaging aftershock in Turshiz, lasting 24 seconds, widlely felt in the region, Belar $(1904: 6)(4)$.

Nov. 3 - Iamaging aftershock in the region of Turshiz, Belar $(1904: 7)\left({ }^{4}\right)$.

Dec. 17 - At 17 h $05 \mathrm{~m}$ strong aftershock at 'Turshiz, Almatov (1905) (1), Belar (1905: v. 218) (4).

I)uring his stay in Turshiz, between the 29th September and 7 October 1903, Almatov experiencer up to 40 aftershocks.

\section{I) ISCUSSION.}

Until recently, Almatov's report was the sole source of information about the Turshiz earthquake of 1903 , which was consequently thought to have been a relatively small magnitude event that caused damage within a comparatively restricted area. around modern Kashmar.

However, certain omissions from this report may lead one to suspect that, Nlmatov who spent nine days in Turshiz looking after the injured did not visit other parts of the epicentral area and that consequently much of what he says about the event, information which he acquired obviously at second hand, does not necessarily imply that either there was no serious damage elsewhere or that the town of Turshiz was the centre of destruction. For instance, Almatov says nothing about the damage to the water-mills west of Turshiz and the clestruction of the carpet industry in the Kundur area, an estimated loss of 50,000 tumans. He should be pretty accurate for Turshiz as he was there, though clearly not accurate for places he did not visit. The fact that he never travelled west of Turshiz and the abrupt change in population density in 1903 west of Shishdiraz gave him the erroneous impression of an epicentral area of rather limiter extent to the west, with Turshiz the centre of destruction. This is similar to more recent erroneous identifications of the real extent of meizoseismal areas reported in the press shortly after an earthquake in Iran; where the largest and most accessible town of the aflected region is considered to be the macroseismic epicentre; for instance Qazvin in the Buyin Zara earthquake of 1962 , Ferlows in the Dasht-i Bayaz earthquake of 1968 and Moraveh Teppe in the Karnaveh earthquake of 1970. 
Taken in conjunction with other sources of information and field evidence, Nlmatov's report suggests that Turshiz was located at the eastermost part of the epicentral zone of the 1903 earthquake which must have extended considerably to the west. Al-Qussy talks about "ab-ambars" along the rlesert track to Shalırud gone dry for two seasons after the earthquake and local information suggests heavy damage with casualties in the Jalalabal - Kadugan region. Clearly maximum damage should have occurred southwest of Turshiz. Surely what emerges from the various reports is not so much that Turshiz was not barly damaged, but more that it was not as badly damagerl, comparatively speaking, as other areas. Sykes who visiter Turshiz six years after the earthquake found that the town harl "suffered considerably during the earthqualie which fortunately affected only a small area"; a statement in agreement with $A$ lmatov, that is in that Turshiz was bally damaged, but that the area of destruction was small.

Although the actual extent, particularly to the west, of the region affecter by the 1903 earthquake camnot be demonstraterl, all the available evidence points to an epicential area which extended from Turshiz in the east, to somewhere between Fadughan and the Kavil, a distance of about 50 kilometres, with a probable epicentre near $35.20 \mathrm{~N}-58.2 \mathrm{oE}$. For a more precise assessment of the extent of the meizoseismal region additional data from local sources of information is needed, for which no foreseeable means of data gathering seems likely.

The extent of the meizoseismal region deduced from the available evirlence is greater than it is emrently thought to be. However, it is rompatible with an earthquake of magnitule $6 \frac{1}{2}$, which seems to be the magnitude of the Turshiz earthquake. The shock was recorded up to distance of $\tilde{5}, 700$ lilometres from the epicentre by very imperfect instruments of low magnification (15 to 125) without damping. Table 1 shows the recorded amplitude at different stations at epicentral distances between 10 and 50 degrees. Averuge magnitudes calculated from amplitudes of the horizontal components of the maximum phase result in an average value of $\mathbf{6 . 4}$, with only small variation in azimuth. This magnitule is consistent with shallow Iranian shocks associated with rarlii of perceptibility of 250 lilometres and with aftershock sequence of about 100 days. As a matter of interest, the aftershork of 30th September was recorded only in Tashlient, and it should have been of a magnitude $5 \%$.

The connection of the Turshiz earthquake with the Dormeh fault is of course only too obvious. However, there is no evidence whatever 
TABIE 1

\begin{tabular}{|c|c|c|c|c|c|c|c|c|c|}
\hline \multirow[t]{2}{*}{ Station } & \multirow[t]{2}{*}{10} & \multirow[t]{2}{*}{ I } & \multicolumn{3}{|c|}{$\begin{array}{l}\text { Onset } \\
\text { Time }\end{array}$} & \multirow{2}{*}{$\begin{array}{c}A_{m} \\
(\mathrm{~mm})\end{array}$} & \multirow{2}{*}{$\begin{array}{c}1_{0} \\
\text { (micr) }\end{array}$} & \multirow{2}{*}{$\begin{array}{c}T \\
\text { (sec) }\end{array}$} & \multirow[t]{2}{*}{$M$} \\
\hline & & & & $m$ & & & & & \\
\hline Tashkent & 10.4 & $\mathrm{R}$ & 01 & 17 & (5) & 22.0 & 367 & 9 & (j.60) \\
\hline 'Tiflis & 12.5 & $\mathrm{E}$ & 01 & 23 & 12 & 10.9 & 156 & 10 & 6.31 \\
\hline & & $\mathrm{E}$ & & & & 7.7 & 110 & 10 & 6.16 \\
\hline & & $\mathrm{E}$ & & & & 8.2 & 1.17 & 10 & (i. 19 \\
\hline & & $M$ & & & & 1.0 & 100 & 10 & (i. 12 \\
\hline Bombay & 20.6 & $M$ & 01 & 27 & 54 & & & & \\
\hline Yur'er & 30.4 & is & 01 & 33 & 54 & 4.0 & & & \\
\hline & & $\mathbf{R}$ & & & & 3.5 & 50 & 12 & (6. 38 \\
\hline & & $\mathbf{R}$ & & & & 4.0 & 57 & 12 & 0.00 \\
\hline Krasnoyarsk & 31.2 & $B$ & 01 & 51 & 42 & 1.0 & 67 & 12 & 6.53 \\
\hline & & 13 & & & & 0.4 & 27 & 12 & 6.13 \\
\hline Kremsmünster & 35.0 & $\mathrm{E}$ & 01 & 28 & 18 & 3.0 & 30 & 14 & 6.20 \\
\hline Triest & 35.1 & $\mathrm{E}$ & 01 & 27 & 56 & 3.3 & 33 & 14 & 6.24 \\
\hline lrkutsk & 36.4 & $\mathbf{R}$ & 01 & 28 & 36 & 10.0 & 100 & 14 & (6. 75 \\
\hline Hamburg & 38.2 & $\mathrm{E}$ & 01 & 28 & 36 & & & & \\
\hline Strasbourgr & 39.2 & $\mathbf{E}$ & 01 & 29 & 50 & & & & \\
\hline Kew & 44.4 & $M[$ & 01 & 45 & 30 & & & & \\
\hline Slide & 45.0 & $M$ & 01 & 46 & 18 & & & & \\
\hline Birlston & 46.0 & $M$ & 01 & 41 & 18 & & & & \\
\hline Edinburgh & 46.0 & M & 01 & 47 & & & & & \\
\hline S. Fornamdo & 51.4 & II & & & & & & & \\
\hline
\end{tabular}

I = type od instrument without damping: $\mathrm{I}=$. Vilne, horizontal pendulum with optical registration; $\mathrm{E}=\mathrm{R}$ (h) pendulum with optieal registration; $\mathrm{R}=$ Zollner-Repsold, horizontal pendulum with optical registration; $B=$ Omori-Boseh, horizontal pemdulum with mechanical registration; $\mathrm{S}=$ Stuckrath, horizotal pendulum.

$A_{m}=$ maximum recorded double amplitude; $A_{0}=$ maximum ground amplitule; instrument constants and aalibration taken from kirnos et al (1961) $\left({ }^{14}\right): T=$ period of oscillation, Soloviev ot al $(1957)\left({ }^{22}\right)$; muliferentiated magnitude based on:

$M=\log \left(. \mathrm{lo}_{\mathrm{o}} / T\right)+1.66 \log (.10)+3.3$,

$.^{0}=$ focal distance in degrees. 
that the 1903 earthquake was associated with movements of this particular major tectonic structure. In the first place, sites located literally on the fanlt or to the north of it, such as Chenar, Kishmar, Kabudan, Nhubam and a number of old mills, sulfered practically no damage. Also, the concentration of widespread damage is in the Shishciraz plain, which extends for about 50 kilometres south-southwest of Turshiz, and so lies to the south of the Doruneh fanlt. With the absence of any evidence of recent fanlting in this segment of the Doruneh fault, the 1903 earthquake should have been associated with the tectonies of the valley between Kull Begu and Siah Kuh, and further to the west with the Bejwird-kuh. This is also the suggestion that arises from the occurrence of the Rikhteh-Ahmatabal earthquake of the 5th October 1962, which also occurred south of the Dorumeh fault and not connected with movements there, Ambraseys (1963) (²).

\section{ACKNOWLEDGEMENTS.}

This is the result of the Joint Project in Engineering Seismology, initiated early in 1973 by the Technical Research \& Standards Bureau of the Plan Organisation, the Arya-Mehr University in Tehran and the Engineering Seismology Section of Imperial College, Isonrlon. The field work was supported equally by the Plan \& Budget Organisation and NERC. The anthors are thankfull to Mr. M. Ittemadi-Irghai and for ruming a survey of the region of Aliabad, sonth of Bardaskian in the spring of 1975 , and to $\mathrm{Mr}$. C. Melville for retrieving unpublished information and reading the manuscript of this paper.

\section{RIEE RENCES}

(1) Armatov, V., 1904-5. - Spisol zemellr"asemii 1903, "Izvest. Post. Tsentral. Scism. Kom.", 2, 1, pp. 157-8, 232, st. Petershmrg.

$\left.{ }^{2}\right)$ Ambraseys, N., 1963. - The Buyin-Zara earlhquale of seplember 1962. "Bull. Scism. Soce Ameriea", 53, p. 737 .

(3) Bavmanteten, vid., 1896. - Puezdla pa roslochmoi Persii. "Geograf.torgav. Islchav, sh. Mat. p. Azii", 63, pp. 1-367.

(") BetaR, A., 1904. - Neneste Erdbeben-Nachrichten. "Die Erdbobenwarte", 3, 3-9, l,aihach. 
$\left(^{5}\right)$ Berberiax, MI, 1973. - Preliminary map of epicentres and focal depths; the seismicity of Iran. "Publ. Geol. Survey of Iran", Tehran.

${ }^{(6)}$ Crank, C., 1861. - Notes in Persia, Thurassan and Afganistan. "Journ. Royal Geogr. Soc.", 31, p. 51.

${ }^{7}{ }^{7}$ EFtekinar-Nezind, .T., 1971. - Geological map of Kashmar. "Publ. Geol. Survey of Iran", Teliran.

$\left({ }^{8}\right)$ Fonster, G., 1798. - 1 journey from Bengal to England. landon, 2, p. 144.

(5) Fraser, I. B., 1825. - Narrative of a journey into Chorasan in the years 1821-2. London, Appendix p. 25.

(10) Gabrier A., 1935. - Durch Persiens II üsten. Strecker \& Schröder, p. 147, St uttgart.

(11) Gaxsswn, A., 1969. - The large earthqualies of Iran and their geological frame. "Eelogae Geol. Helv.", 62, 2, p. 443.

(12) Geological Map of Iran, 1959. - "National Iranian Company", Tehran.

(13) Grasek, S. V. (1903). - Ezhemisiachenii seismicheshi binllelin. "Tifliskoi Fizicheck. Observ.", 4, 10, 13, Tbilisi.

(14) Kirvos D., Kinarin D., Shebalix N., (1961). - Razviti instrumentalnih seismicheskih mabliudenii v SSSR. Akadem. Nauk, Izd., Moscow.

$\left.{ }^{(15}\right)$ Lxyitski, G., 1905. - Bulletin de la Commission Centrale Seismique Permename. "Akad. Imper. Nauk", 2, p. 157 St. Petersbourgr,

${ }^{(16)}$ Matcolit, J., 1829. - Hislory of Persia. 2, ftnt p. 146.

(17) Mucxe, .T., 1911. - List of earthqualies 1899-1903. "British Assoc. Advanc. Sci.", p. 65, Portsmouth.

$\left({ }^{18}\right)$ Monajer-AshJal A., Benzad H., Berberiax M., 1975. - Reflections on. the rigidity of the Lut block and recent crustal deformation. in Easterm. Iran. "Tectonophysics", 25, p. 292.

${ }^{(19)}$ Mustawfi, Hamditati, Qazwin, 1894. - Nuzhal-al-Qulub. Chapter 13, fol. 143, Bombay.

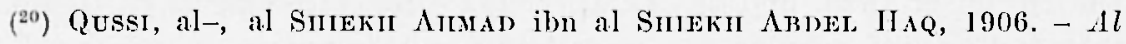
baralin ua al zalzal. Baghdad, Taymur, p. 249.

${ }^{(21)}$ Snebera, A., 1932. - Die Erdbeben. in "B. Gutenbergr's Handbuch der Geophysik", 4, p. 815 .

${ }^{(22)}$ Soloviev S., Simbalix, N., 1957. - Opredelenie intensivnosti zemletrasenii pa smecheniiu pachvi v poverlhnostih volnah. "Izvest. Akad. Nauk", Ser. Geof., 7, Moscow.

${ }^{(23)}$ Stant, A. F., 1911. - Erdbeben. "Inandbuch der Regional. Geol.", Persien, 4, chpt. V-VI, p. 5.

(21) STEwart C., 1881. - The country of the Tekke Turkomans. "Proc. Royal Geogr. Soc.", 3, p. 524.

${ }^{(25)}$ STöcklix, J., Nabavı Ml, 1973. Tectonic map of Iran. "Geolog. Survey of Iran", Tehran.

${ }^{(26)}$ STraxie, Id, G., 1966. - The lands of the Eastern Caliphate. F. Cuss, p. 355 . 
TIIE SEISMICITY OF IRAN. TIIE TURSIIZ KIIORASSAX EARTIQUAKE. . 269

(27) Srkes, P. M., 1911. A sirth journey in Persia. "The Geograph. Journ.", 37, p. 159, London.

(28) TAMs, E. 1908. - Geographische Verbreitung und erdwissenschaftliche Bedeutung der aus den Erdbebenbeobachtungen des Jahres 1903 sich ergebenden Epizentren. "Beitr. z. Geoph.", 9, p. 328, Leipzich.

(29) Tehalenko J., 1973. - The Kashmar, Turshiz, 1903 and Torbat-e Heidariyeh south earthquakes in central Khorassan, Iran. "Annali di Geofisica", XXVI, pp. 29-40, Rome.

(30) Tchalenko, J., Berberiax M., Benzadi H., 1973. - Seismic and geomorphic evidence of recent activity on the Doruneh fault, Iran. "Tectonophysics", 19, pp. 333-341.

(31) Weigaxi, B., 1903. - Gefülde Beben. Monatsbericht d. Keiserl. Hauptst. f. Errbebenforsehung $z$. Strassburg, 9-11.

$\left({ }^{32}\right)$ Wellaman, H., 1966. - Active faults of Iran, Afganistan and Palistan. "Geolog. Rundsch", 55, pp. 716-735. 